\title{
SEASONAL LABOUR MARKET RIGIDITIES: IMPACT ON FARM EMPLOYMENT AND WAGES IN NIGERIA
}

\author{
Solomon Abayomi Olakojo ${ }^{1}$
}

\section{Summary}

This study investigates the sensitivity of wages and employment in the agricultural sector to seasonal demand and productivity conditions facing Nigerian farmers. It develops a data consistent analytical model that incorporates seasonality in farm employment and wages. This was tested empirically using the Living Standards Measurement StudyIntegrated Surveys on Agriculture (LSMS-ISA) for Nigeria for the year 2012/2013.

The study finds that, during harvest, farmers are significantly less likely to employ male labourers and pay them lesser wages. Contrarily, female labourers are more likely to be employed and paid higher wages in harvest. The decline in male employment and increase in female employment during harvest is stronger for medium (-0.15\%) and large scale farmers $(0.22 \%)$, respectively. The decline in male wages and increase in female wages during harvest is stronger for large (-0.25\%) and low scale farmers $(0.22 \%)$, respectively.

This study recommends policy options to minimize undesired employment effect of seasonality.

Key words: agricultural seasonality, farm wages and employment, non-parametric regressions

JEL: J43, Q10, Q14

\section{Introduction}

Agricultural sector plays a significant role in employment generation in many African countries because the bulk of Gross Domestic Product comes from agricultural activities, dominated by crop production. For instance, agricultural sector employs 65 percent of Africa's labour force and accounts for 32 percent of gross domestic product thus making it an important tool in the fight against poverty (World Bank, 2013) ${ }^{2}$. In rural

1 Solomon Abayomi Olakojo, Ph.D. Lecturer, University of Lagos, Department of Economics, Nigeria, Phone: +234 7033072945, E-mail: solomonolakojo@gmail.com. Acknowledgment: The Author acknowledges the contribution of Odiche Nwabiukwu (Intern at CSEA) to the literature review section. The usual disclaimer applies.

2 Africa - Fact Sheet: The World Bank and Agriculture in Africa.

EP 2016 (63) 4 (1123-1140) 
Africa, the role of agricultural sector in employment generation is expected to be more significant. However, seasonality of agricultural activities is associated with variations in employment which creates imbalance in labour market outcomes between seasons.

Nigerian agricultural sector is characterised with seasonal unemployment because farming activities are often skewed towards certain times of the year - planting or harvesting season. For instance, the third quarter of the year has historically recorded higher job numbers compared to other quarters, as farmers employ more hands to assist on the farms (NBS, 2015). Specifically, in the third quarter of 2015, over 70 percent of the informal sector jobs created was related by rural agriculture due to the beginning of the harvest season ${ }^{3}$, especially of maize and yam crops. This is not surprising since Nigeria is the largest producer of maize in Africa with nearly 8 million tons of maize production, which is about 3\% of the total Sub-Saharan African maize harvest (www. iita.org/maize). Besides, 94\% of world yam production comes from West Africa with Nigeria alone producing 71\%, equalling more than 37 million tons (www.iita.org/yam). This makes the nation the world largest producer of yam.

Besides the effects of seasonality on rural welfare (through earning and employment instability), the variation in the production and supply of agricultural commodities between farming and off-farming periods, on one hand, has implications for revenue loss for farmers, as farm products flood market during harvest leading to crash in prices. On the other hand, sudden rise in prices of food items, especially during the off- harvest farming seasons, has implications for food prices shocks among Nigerian households. This has been acknowledged as one of the major shocks negatively affecting households in Nigeria (Integrated Surveys on Agriculture 2013; Integrated Surveys on Agriculture 2014). It is also logical to state that the off-farming periods will be associated with rural-urban migration for the household to smooth their earnings and consumption patterns, thus compounding urban demographic problems.

There is scanty empirical evidence relating to seasonal agricultural labour market imperfections in Nigeria and this study seeks to fill this gap. While some studies have acknowledged the existence of this phenomenon and its effects on wages and employment (Bardhan, 1979; Canwat, 2012), some studies consider rural agricultural markets to be competitive, with wage determined completely by the marginal product of labour. Many studies (Basu, 2011; Bardhan, 1979) have opposed this theory by pointing out the presence of involuntary unemployment in the lean seasons, often caused by availability of limited number of permanent labour contracts, which is not expected in a competitive setting. Bardhan (1979) also dismissed other popular wage theories like the subsistence

3 Notwithstanding, this period (of high employment) also coincides with period of planting of second maize stream as well as yam harvesting. 
wage theory ${ }^{4}$, which assumed the presence of a constant wage invariant to changes in season and productivity conditions. His (Bardhan) research, which uses National Sample Surveys (NSS) from rural West Bengal, was generated using a simple theoretical model which incorporates some of the factors ignored by these popular theories.

Seasonality also disrupts labour market functions and affects household production (labour demand) and consumption (labour supply) decisions. According to Le (2010), in a complete and efficient labour market, household will behave as a profit maximizing entity, with production decisions completely separate from personal preferences. Many studies (Benjamin, 1992; Grimard, 2000; Le, 2010) have tested this separation which yielded mixed results. Although the separation model (SM) has been disrupted in many areas, different tests yield different results depending on the scope and location of the study. For e xample, Benjamin (1992) tested this separation, theorising that in a functioning labour market, household composition would not be an important determinant of farm labour use. Analysing the results of a survey of farmers in the rural town of Java, Indonesia, Benjamin (1992) failed to reject the null hypothesis that farm labour allocation was independent of household composition. Grimard (2000) and Le (2010) studies rejected the separation model in rural towns located in Ivory Coast and Vietnam, respectively.

On one hand, risk neutral landlords enter into permanent contracts with risk averse households who wish to gain a steady, albeit lower, income (Bardhan, 1983). Although this practice is more advantageous than tied labour in theory, studies (Basu, 2011; Gulesci, 2011) have brought attention to potential challenges permanent workers may face. For example, Basu (2011) points that they are vulnerable to debt bondage, as a result of poor credit facilities (Basu, 2011), and Bardhan (1979) alludes to the risk of exploitation by oligopsonistic landlords. Gulesci (2011) also reveals a causal link between labour tying and poverty by conducting a randomized observational experiment, using the results of a poverty alleviation program in Bangladesh. He found that as households gained better access to employment opportunities in non-farm sector, they moved from permanent (or tied) labour contracts, which usually offers lower returns, riskier, but higher yielding jobs.

On the other hand, the employer may be incentivized to enter permanent labour contracts to minimize recruitment costs and possible shortfalls from production failure (Bardhan, 1979). This is advantageous for employees that manage to secure these contracts; they

4 The subsistence theory of wages, advanced by David Ricardo and other classical economists, was based on the population theory of Thomas Malthus. It held that the market price of labour would always tend toward the minimum required for subsistence. If the supply of labour increased, wages would fall, eventually causing a decrease in the labour supply. If the wage rose above the subsistence level, population would increase until the larger labour force would again force wages down.

5 According to Basu (2011), poor credit institutions lead labourers borrow from richer landlords in the lean season with a pledge to repay the loan with labour services in the peak season.

EP 2016 (63) 4 (1123-1140) 
are privy to higher annual wages, consumption credit, and even small plots of land to cultivate or build on (Bardhan, 1979; Eswaran \& Kotwal, 1985). Bardhan (1979) also claimed that this practice will help the employer capture the production benefits of a higher wage, according to the efficiency wage theory. Eswaran and Kotwal (1995) proposed an alternate theory that permanent workers are given these benefits to discourage them from shirking work; keeping them at a higher utility will also ensure their loyalty. Employers can also minimize supervision costs (despite a possible increase in recruitment costs) because workers are trusted to perform complicated tasks usually left to trusted family workers.

Moreover, labour demand is often highly elastic in slack periods (Bardhan, 1979b), the majority of farm workers are unable to secure permanent labour contracts, and need to depend on peak season labour demand for employment. This class of workers is specifically targeted in Basu's study about the impact of employment guarantee schemes $^{6}$ (EGS) on rural labour markets. Basu evaluates the impact of EGS on wages and agricultural production, and found that EGS could cause a positive impact on both casual $^{7}$ and permanent wages, as well as agricultural productivity in general. The study concludes that EGS is a good way of combating involuntary unemployment caused by seasonality. Other possible solutions include, improving access to credit facilities, easing the barriers to off farm employment, and improvements in available agricultural technology. Basu alludes to the first of these solutions, stating that improved credit facilities may be useful in preventing households from falling into debt bondage.

Another study by McCullough (2015) suggests that other sectors may be able to absorb the excess labour from the agricultural sector. However, this theory does not consider that these barriers may be created by skills gaps, which prevent poor, often uneducated farmers from participating in off farm sectors. Canwat (2012) also suggests that improvements in technology will be able to soften the seasonal divide, by allowing certain agricultural activities to take place regardless of season.

Devereux and Longhurst (2009) review selected African Development Bank (AfDB), International Fund for Agriculture (IFAD) agricultural projects as well as other case studies to examine whether the projects targeted at supporting agriculture-based livelihoods in Africa account for seasonality in their design, delivery and evaluation. The basic finding is that seasonality is very often ignored in the conceptualisation and design of agricultural projects. He concluded that this has detrimental consequences for projects' performance and farmers' wellbeing.

Given the above background, this study seeks to investigate the effects of seasonal imperfections and rigidities on farm employment and wages in Nigeria. The study hypothesises that seasonal imperfections and rigidities - by lowering farming

6 Employment Guarantee Scheme is a policy aimed at creating full employment

7 This may be dependent on the relative productivity of EGS labourers compared to their agricultural counterparts. 
activities - affects employment and wages more deeply at one season than the other.

The rest of the paper is organised as follows; following the introductory section, section two looks at methodology. In section three, data sources and description is presented. While section four dwells on the results, section five concludes the study and states policy recommendation.

\section{Methodology}

\section{Conceptual Framework}

The main objective of this study is to investigate the extent to which seasonal labour market imperfections and rigidities influence agricultural employment and wages in Nigeria. In this regard, a theoretical model, which explains how the seasonal labour imperfection and rigidity influences employment and wage gaps, is developed. This framework is related to Bardhan (1979, 1983), Eswaran and Kotwal (1985), Basu (2011) and Gulesci (2015).

This framework assumes two sets of households: the landlords and the landless labourers. The representative landlord produces a crop whose production rigidly spread over two seasons; the harvest farming (period 2, q2) and planting (period 1, q1). The planting season labourers are assumed have some attributes permanent workers since planting activities extents to other farm activities such as weeding, farm maintenance and even harvesting.

Hence,

$Q=f\left(q_{1}, q_{2}\right)$

Equation (1) implies that farming is assumed to be a continuous process and there can be no unique distinction between output at harvest and planting seasons. For instance, clearing the fields, planting, weeding and other farm maintenance is part of crop production process ending with harvest. Therefore, for the landlords, outputs in both periods are identically equal. The inputs require for production in the two periods is given as:

$$
\begin{aligned}
& q_{1}=k^{\alpha_{1}} l^{\alpha_{2}} h^{-\alpha_{3}}, \forall \alpha_{1+} \alpha_{2+} \alpha_{2}<1 \\
& q_{2}=k^{* \beta_{1}} l^{* \beta_{2}}\left(k^{\alpha_{1}} l^{\alpha_{2}} h^{\alpha_{3}}\right)^{\beta_{3}}=Q, \forall \beta_{1}+\beta_{2}+\beta_{3}=1
\end{aligned}
$$

Equation (2) implies that production of the representative crop in period 1 (unharvested crop) is a function of capital employed $(\mathrm{k})$ in period 1 (such as Plough, Harrow, and Planter), permanent labour employed ( $l$ ), land (fixed factor, h) and it exhibits a decreasing return to scale in fixed factors (land and capital). Hence, it represents production in the short run. In equation (3), harvest is a function of capital $\left(\mathrm{k}^{*}\right)$ (such as Grain Cart, Farm truck, Grain dryer and Harvester), tied labour employed during 
harvest period $\left(l^{*}\right)$ and amount of unharvest crop (q1) - a necessary investment to achieve harvest (q2). Hence, equation (3) could be described as a production in the medium term. Further, maximization of $\mathrm{q} 2$ implies maximization of $\mathrm{Q}$ because prices can reasonably be attached to harvest crops unlike at planting period when farming investment is made. Also, some of the inputs employed in the planting season, especially permanent labour and land, are retained all through the farming season. This explains the reason for arguments $l, \mathrm{k}$ and $\mathrm{h}$ in equation (3).

\section{The Representative Landlord's Problem}

The representative landlord seeks to minimize total cost of producing Q subject to harvest output, $\mathrm{q}_{2}$. This is given by;

$$
\begin{array}{ll}
\text { Min } & {\left[r^{*} k^{*}+w^{*} l^{*}+T C q_{1}\right]} \\
\text { s.t } & q_{2}-k^{* \beta_{1}} l^{* \beta_{2}} q_{1}^{\beta_{3}}
\end{array}
$$

This problem can be set up and solved as follows:

$$
\begin{aligned}
& L=r^{*} k^{*}+w^{*} l^{*}+T C q_{1}+\lambda\left(q 2-k^{* \beta_{1}} l^{* \beta_{2}} q_{1}^{\beta_{3}}\right) \\
& \frac{\partial L}{\partial l^{*}}=w^{*}-\lambda \beta_{2} k^{* \beta_{1}} l^{* \beta_{2}-1} q_{1}^{\beta_{3}}=w^{*}-\lambda \beta_{2} \frac{q_{2}}{l^{*}} \\
& \frac{\partial L^{2}}{\partial^{2} l^{*}}>0 \\
& \text { (Sufficient condition for cost minimization) }
\end{aligned}
$$

Hence,

$$
\beta_{2}=\frac{w^{*} l^{*}}{\lambda q_{2}}
$$

Similar steps can be repeated to derive the marginal products of capital and marginal contribution of unharvest crop. Meanwhile, attention is on labour since agricultural production significantly remains less mechanised in Nigeria.

Recall that $\beta_{1}+\beta_{2}+\beta_{3}=1$. Hence,

$$
\frac{r^{*} k^{*}}{\lambda q_{2}}+\frac{w^{*} l^{*}}{\lambda q_{2}}+\frac{T C q 1}{\lambda q_{2}}=1
$$

Rearranging equation (10) yields; 


$$
\lambda=\frac{T C(Q)}{q_{2}}
$$

Substituting (10) in (8) and making $l^{*}$ the subject gives the optimum level of tied labour that minimises cost of producing $\mathrm{Q}$ as;

$$
l^{*}=\frac{T C(Q) \beta_{2}}{w^{*}}
$$

Applying duality principle to equation (11) by assuming employment of tied labour that minimises cost of producing Q also maximises its output yields;

$l^{*}=\frac{Q \beta_{2}}{w^{*}}$

However,

$l=\frac{q_{1} \alpha_{2}}{w}$

Hence,

$\frac{Q \beta_{2}}{w^{2} *}>\frac{q_{1} \alpha_{2}}{w^{2}}$

Equation (14) implies that the labour engaged in harvest is greater than that of the planting season. However, higher farm labour influx in harvest season reduces wages.

Comparing equation (12) and (13), it is cleared that the slope of demand for tied labour is more inelastic than the demand for permanent labour. This can be represented in a partial equilibrium analysis as follows:

Figure 1. Labour demand in planting and harvest season

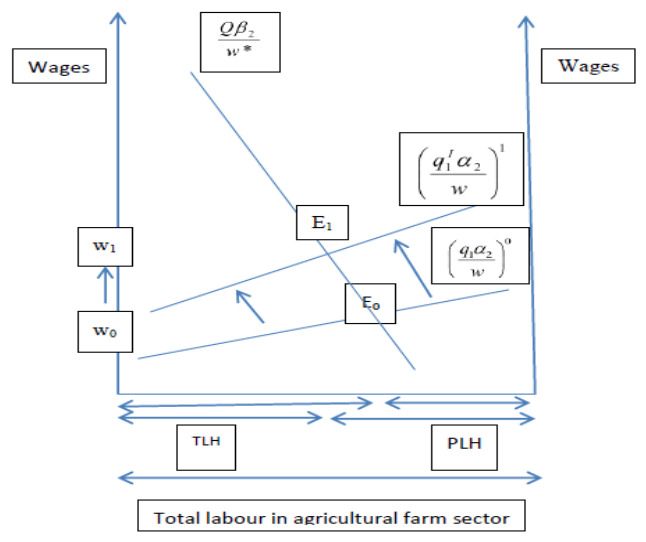

Source: Author's construction

EP 2016 (63) 4 (1123-1140) 
Note: TLH and PLH imply tied and permanent labour hired, respectively. Figure 1 is constructed from the demand curves for both tied and permanent labour with one facing the other.

From the initial equilibrium $\left(\mathrm{E}_{0}\right)$ and wage $\left(\mathrm{w}_{0}\right)$, the labour employed in harvest season is higher than planting season indicated by the first two arrows below Figure 1. Hence, in planting season, tied labourers who are unable to get work in the farm sector are assumed to migrate to non-farm sector in search of employment, necessary to smooth their consumption paths. This shrinks the total labour available in farm sector and will imply higher marginal product of the remaining labour. Since labour is paid the value of its marginal productivity, wages also increase thus contracting profit of the representative landlord, leading to reduction in farm output, Q.

Assuming there is technology (such as irrigation, improved seeds and counter-seasonal grain market operations) that enhances q1 production, the permanent labour demand

pivoted (to become more inelastic) and shifts from $\left(\frac{q_{1} \alpha_{2}}{w}\right)^{0}\left(\frac{q_{1}^{1} \alpha_{2}}{w}\right)^{1}$ to and the new equilibrium condition is established at $\mathrm{E}_{1}$. This point is associated with higher equilibrium wage rate (from $\mathrm{w}_{0}$ to $\mathrm{w}_{1}$ ) and near balance in the labour demanded in the two seasons. That is, some of the tied labourers that are only engaged in harvest season can now be engaged as permanent workers. On one hand, since the wage of permanent labourers guarantees his expected lifetime utility and that of the tied labourers is determined by the output in harvest period only, it is logical to conclude that both permanent and tied labour are better-off with higher wages. On the other hand, the technology that improves q1 also increases permanent labour efficiency, leading to higher output and farm profitability.

\section{Estimation Procedures}

Emanating from the above framework, the estimation sequence is to first conduct a descriptive statistics of seasonality of employment and wage as well as chi-square difference test of harvest and planting seasons relating to variables of interest obtainable from the agriculture questionnaire of LSMS-ISA surveys. Consequently, non-parametric regression models (which uses bootstrapping technique), otherwise regarded as quantile or robust regression are estimated. This is necessary to deal with presence of outliers posed by the nature of heterogeneous farm employment and wages depending on whether a farmer is a large, medium or small scale. The labour farm labour market outcomes based on the reasoning previously derived can be stated as:

$$
Y_{i s t}=\alpha+\beta h h w+\lambda d t+\rho \pi_{i s}+\varepsilon_{i s t}
$$

$\mathrm{Y}_{\text {ist }}$ is the labour market outcomes such as employment and wages. $h h w$ is the household member's labour farm input (number of hours work per day on the farm). The negative coefficient implies that farmer substitutes own farm employment for hired employment. 
This characterised peasant farming in Nigeria. dt is a dummy which is equal to 1 if the observation is from harvest and zero otherwise, capturing factors that would cause changes in the labour market outcomes in the absence of a policy change. $\prod_{\text {is }}$ is farmers' location such as rural and urban. $\varepsilon_{i s t}$ is error term.

In terms of variables considered, the focus is on the key items such as the number of hired labourers in planting and harvest seasons, number of days they are hired, wages paid, gender of the employed and harvest sales.

\section{Data Sources and Description}

The study obtains its data mainly from the Living Standards Measurement StudyIntegrated Surveys on Agriculture (LSMS-ISA) for Nigeria in the wave 2 panel studies for the year 2012/2013. The NGHS-ISA data was collected in two phases; the postplanting period (September to November 2012) and post-harvest period (February to April, 2013, respectively). The survey sampled 5,000 households (about 12, 948 individuals) with representative at the national, urban/rural and the six geopolitical zones of Nigeria. The Nigeria LSMS-ISA instruments included household, agriculture, and community questionnaires covering post-planting and post-harvest periods.

In this survey, all sample households were administered the multi-topic household questionnaire, while the households involved in agricultural activities (through ownership and/or cultivation of land, livestock, and fishing) were administered the agriculture questionnaire. The agriculture questionnaire solicited information on land areas, physical characteristics, labour and non-labour input use, extension services, other agricultural incomes, and crop cultivation and production, with reference to rainy and dry seasons. Also, some of the relocated households were successfully tracked and interviewed using a modified questionnaire.

\section{Results}

This section presents the major findings and discussion. It equally links some of the results with the theoretical positions relating to seasonality and labour market imperfections in agriculture.

\section{Characterisation of Nigeria's Farm Sector}

The essence of the descriptive statistics, presented in Table 1, is to assess the nature of the data to be used in subsequent estimations in order to guide against misspecifications. The standard deviations (stds) and coefficients of variations (CVs) indicate that all variables, except number of days and hours farm managers work on the farm, are nonnormally distributed given the values of stds and CVs above 0.5 . In other words, these variables exhibit significant skewness. This is also indicated by the gap between the means (averages) and maximum values of each variable. Given the characteristics of the key variables, employing linear regression will yield biased estimations; hence 
the justification for employing non-parametric or robust regression techniques, which consider the influence of outliers.

Table 1. Description of variables

\begin{tabular}{|c|c|c|c|c|c|c|c|c|c|c|}
\hline Stats & $\begin{array}{l}\text { No of } \\
\text { weeks } \\
\text { Hh } \\
\text { work }\end{array}$ & \begin{tabular}{|l} 
No of \\
days \\
Hh \\
work
\end{tabular} & $\begin{array}{l}\text { No of } \\
\text { hrs } \\
\text { Hh } \\
\text { work }\end{array}$ & $\begin{array}{l}\text { Men } \\
\text { Emp }\end{array}$ & $\begin{array}{l}\text { Days } \\
\text { Men } \\
\text { work }\end{array}$ & $\begin{array}{l}\text { Men wages } \\
\text { (naira) }\end{array}$ & $\begin{array}{l}\text { Women } \\
\text { Emp. }\end{array}$ & $\begin{array}{l}\text { Days } \\
\text { Women } \\
\text { work }\end{array}$ & $\begin{array}{l}\text { Women } \\
\text { wages } \\
\text { (naira) }\end{array}$ & $\begin{array}{l}\text { Harvest } \\
\text { sales }\end{array}$ \\
\hline Min & 0 & 0 & 0 & 0 & 0 & 0 & 0 & 0 & 0 & 0 \\
\hline Max & 52 & 7 & 14 & 300 & 800 & 70000000 & 200 & 99 & 30000 & 2600000 \\
\hline mean & 13.5 & 4.7 & 5.9 & 2.0 & 5.1 & 118834.0 & 0.8 & 3.7 & 1118.1 & 28839.7 \\
\hline $\mathrm{Sd}$ & 14.9 & 1.7 & 2.1 & 5.8 & 20.4 & 2330006.0 & 3.1 & 5.5 & 1742.9 & 74222.2 \\
\hline $\mathrm{Cv}$ & 1.1 & 0.4 & 0.4 & 2.9 & 4.0 & 19.6 & 3.8 & 1.5 & 1.6 & 2.6 \\
\hline
\end{tabular}

Source: Computed using STATA

Moreover, crop farming is also dominated by few crops as indicated in Table 2 . The leading crop among them is cassava, maize and yam grown by $16.6 \%, 15.7 \%$ and $11.9 \%$ of the surveyed farmers, respectively. Overall, the selected 10 crops are grown by $77.2 \%(9,993)$ of the surveyed farmers. Meanwhile, average harvest sales from these crops give some insights into some of the challenges facing Nigerian farmers. First, farmers in the lowest echelon ( 0 and 100,000 naira) of harvest sales are significantly high (90.2\%) (Table A1). Second, the two leading most grown crops (cassava and maize) do not give the highest harvest sales, while crops such as yam and rice grown by $7.2 \%$ and $2.6 \%$ of surveyed farmers yield the highest average harvest sales of 83764.36 and $82,700.35$ naira, respectively. This outcome, in the case of rice farming, implies weak agro-allied rice industrialisation in Nigeria. In other words, majority of Nigerian farmers are constrained to grow crops that require less automated processes, even though they are less profitable, unlike rice requiring post-harvest, stacking, handling, threshing, cleaning and hauling to ensure good quality and marketability. Yam seems to be the most rewarding among the leading crops grown by many Nigerian farmers, though production is declining in some traditional producing areas. This has been attributed to declining soil fertility, increasing pest pressures, and high cost of labour (www.iita.org/yam).

Table 2. 10 Leading (of the 92 sampled) crops grown by Nigerian farmers

\begin{tabular}{|l|r|r|r|}
\hline CROP CODE & $\begin{array}{l}\text { Number of } \\
\text { farmers }\end{array}$ & Percentage & \multicolumn{2}{|l|}{$\begin{array}{l}\text { Average harvest sales } \\
\text { (Naira) }\end{array}$} \\
\hline CASSAVA OLD & 2,128 & 16.43 & 48060.38 \\
\hline MAIZE & 1,952 & 15.08 & 44574.5 \\
\hline GUINEA COURN/SORGHUM & 1,533 & 11.84 & 45384.6 \\
\hline
\end{tabular}




\begin{tabular}{|l|r|r|r|}
\hline BEANS/COWPEA & 1,160 & 8.96 & 37847.63 \\
\hline YAM & 937 & 7.24 & 83764.36 \\
\hline MILLET/MAIWA & 910 & 7.03 & 47185.56 \\
\hline GROUND NUT/PEANUTS & 415 & 3.21 & 38302.5 \\
\hline RICE & 332 & 2.56 & 82700.35 \\
\hline OKRO & 321 & 2.48 & 5514.73 \\
\hline COCOYAM & 305 & 2.36 & 15244.13 \\
\hline Sub-total & $\mathbf{9 , 9 9 3}$ & $\mathbf{7 7 . 1 9}$ & \\
\hline Total & 12,948 & 100 & \\
\hline
\end{tabular}

Source: Computed using STATA

Besides, crops like cassava and maize, as leading crops grown in Nigeria, require further value-addition to make them more marketable; thus inadequate storage (especially in the case of cassava) and other facilities to add the necessary value-addition as well as labourious activities involve using manual method often constraint farmers to sell them in raw forms leading to lower harvest sales among a number of Nigerian farmers. The challenges of inadequate agro-allied industrialization is also buttressed in Table 3 where $74.9 \%$ of the farmers indicated no use of equipment or machine on plot in the new planting season, compared to $35.6 \%$ who indicated that they sold unprocessed crops in harvest (Table 4). This implies that most of the processed farm outputs are done manually, which is often labourious and inefficient.

Table 3. The use of equipment/machine on plot since last year

\begin{tabular}{|l|r|r|}
\hline & \multicolumn{1}{|l|}{ Freq. } & percentage \\
\hline $\begin{array}{l}\text { Do not use any equipment/ } \\
\text { machine }\end{array}$ & 4329 & 74.9 \\
\hline Use equipment/machine & 1453 & 25.1 \\
\hline Total & 5782 & 100 \\
\hline
\end{tabular}

Source; Computed using STATA

Table 4. Selling of unprocessed crops in harvest

\begin{tabular}{|l|r|r|}
\hline & Freq. & Percentage \\
\hline No & 6404 & 64.4 \\
\hline Yes & 3533 & 35.6 \\
\hline total & 9937 & 100 \\
\hline
\end{tabular}

Source: Computed using STATA 


\section{Seasonal Analysis}

Generally, significant difference exists in the time spent by farmers on farming activities in harvest and planting, with more time spent during planting season (Table 5). This shows that most farmers work more as permanent workers and then engage tied labour in harvest. However, slight variations exist across the categories of hours farmers spent on the farm. Besides farmers on full time farm employment (category of farmers spending between 6 and 10 hours), other categories of farmers spent more hours on the farm during harvest than planting season.

Table 5. Hours Farmers spend on Farm Work

\begin{tabular}{|c|c|c|c|}
\hline & \multicolumn{2}{|c|}{ Season } & \multirow[b]{2}{*}{ Total } \\
\hline $\begin{array}{l}\text { Number of hours farmers } \\
\text { work categories }\end{array}$ & Planting & Harvest & \\
\hline 0 & 0 & 33 & 33 \\
\hline 5 & 2,194 & 2,337 & 4,531 \\
\hline 10 & 3,117 & 2,707 & 5,824 \\
\hline 15 & 1 & 89 & 90 \\
\hline Total & 5,312 & 5,166 & 10,478 \\
\hline Pearson Chi2 & \multicolumn{2}{|c|}{$94.35 * * *(0.000)$} & \\
\hline
\end{tabular}

Source: Computed using STATA

Note: probability value is in parenthesis

Both male and female farm employment is significantly higher in harvest season than in planting season; however, wages and number of days engaged labourers in planting season are significantly higher, especially among the low and medium scale farmers (Table 6). This is theoretically linked with the augment in equation (15) and Figure 1. First, influx of labour during harvest may be responsible for lower wages in harvest relative to planting season. Second, by assuming that utility is tied to wages, the wages differential between planting and harvest season implies lower utility for farm employees in harvest season. This is in line with the theoretical argument that the wages of permanent worker (planting season worker) must be high enough to guarantee his lifetime utility and sufficiently greater than his opportunity utility. Otherwise, he would not supply an acceptable level of effort (Eswaran and Kotwal, 1995). The differences between planting and harvest seasons relating to the numbers of days land owners engage permanent and tied labour also buttressed that tied labour is engaged for a limited number of days compared to his permanent labour counterpart. 
Table 6. Results from Difference Tests by Season

\begin{tabular}{|c|c|c|c|c|c|c|}
\hline & \multicolumn{3}{|c|}{ Male Employees } & \multicolumn{3}{|c|}{ Female Farm Employees } \\
\hline & \multicolumn{6}{|c|}{ Season ID (1=harvest) } \\
\hline Employment categories & 0 & 1 & Total & 0 & 1 & Total \\
\hline 0 & 1,746 & 3,986 & 5,732 & 3,125 & 4,893 & 8,018 \\
\hline 9 & 2,774 & 1,571 & 4,345 & 1,252 & 687 & 1,939 \\
\hline 29 & 288 & 96 & 384 & 67 & 59 & 126 \\
\hline 300 & 18 & 1 & 19 & 8 & 8 & 16 \\
\hline Total & 4,826 & 5,654 & 10,480 & 4,452 & 5,647 & 10,099 \\
\hline \multicolumn{7}{|l|}{ Statistics } \\
\hline \multirow[t]{2}{*}{ Pearson Chi2 (3) } & \multicolumn{3}{|c|}{$1300(0.000)$} & \multicolumn{3}{|c|}{$419.5(0.000)$} \\
\hline & \multicolumn{6}{|c|}{ Season ID (1=harvest) } \\
\hline $\begin{array}{l}\text { No of days engaged } \\
\text { labourers on farm } \\
\text { categories }\end{array}$ & 0 & 1 & Total & 0 & 1 & Total \\
\hline 0 & 25 & 12 & 37 & 23 & 7 & 30 \\
\hline 20 & 3,004 & 1,646 & 4,650 & 1,320 & 737 & 2,057 \\
\hline 60 & 77 & 8 & 85 & 13 & 1 & 14 \\
\hline 99 & 3 & 2 & 5 & 0 & 3 & 3 \\
\hline 800 & 12 & 0 & 12 & 0 & 0 & 0 \\
\hline Total & 3,121 & 1,668 & 4,789 & 1356 & 748 & 2,104 \\
\hline \multicolumn{7}{|l|}{ Statistics } \\
\hline \multirow[t]{2}{*}{ Pearson Chi2 (3) } & \multicolumn{3}{|c|}{$31.42(0.000)$} & \multicolumn{3}{|c|}{$12.39(0.006)$} \\
\hline & \multicolumn{6}{|c|}{ Season ID (1=harvest) } \\
\hline wages categories & 0 & 1 & Total & 0 & 1 & Total \\
\hline 0 & 48 & 32 & 80 & 23 & 38 & 61 \\
\hline 18000 & 2,972 & 1,627 & 4,599 & 1,298 & 709 & 2,007 \\
\hline 30000 & 31 & 4 & 35 & 0 & 2 & 2 \\
\hline 70000000 & 69 & 2 & 71 & 0 & 0 & 0 \\
\hline Total & 3,120 & 1,665 & 4,785 & 1,321 & 749 & 2,070 \\
\hline \multicolumn{7}{|l|}{ Statistics } \\
\hline Pearson Chi2 (3) & \multicolumn{3}{|c|}{$42.07(0.000)$} & \multicolumn{3}{|c|}{$22.18(0.000)$} \\
\hline
\end{tabular}

Source: Computed using STATA

Note: P-values are in the parentheses. *** implies significant at $1 \%$ level.

There is gender disparities in farm labour market with male farm employees having higher employment, wages and engaged for a longer period of time than female farm employee (also see Table 1). However, employment of women especially among the low scale farmers is higher in harvest period. In the case of case of cassava- the most grown crop, this outcome is connected to low mechanisation. That is, due to low level of 
mechanization such as mechanised graters, post-harvest processing including washing, peeling, resting, fermenting and heat treatment is an important part of women's daily work in rural areas.

\section{Effect of Seasons on farm wages and employment}

The non-parametric estimations presented in Table 7 and 8 quantify the impact of seasons and other control variables on farm wages and employment. During the harvest, male farm wages are generally reduces by $0.26 \%$, the effect is however only significant among the large scale farmers who are categorised in the upper 75 percentile (Table 7). Contrary to male wages, female wages increase by $0.02 \%$ in harvest, with significant impact only with the low scale farmers who are categorised in the lowest 25 percentile (Table 7). These outcomes imply that men wages are relatively higher in planting season, an indication that men farm employees are more of permanent labour compared to their female counterparts who are mainly tied labour characterised with increased wages in harvest. It is also realised that farm wages and land lords' farm activities are compliments, given the positive significant coefficients of hours the land lords spend on the farming activities and wages paid to hired workers. This is most relevant to large scale farmers. Meanwhile, wages is not determined by location, be it rural or urban.

Moreover, during the harvest, male employment are generally reduces by $0.14 \%$, the effect is also significant among the medium and large scale farmers who are categorised in the 50 and upper 75 percentiles with coefficient of $0.15 \%$ and $0.08 \%$, respectively (Table 8 ). In contrast, female employment increases by $0.12 \%$ in harvest but this is only noticed with the large scale farmers, categorised in the highest 75 percentile. These outcomes imply that men are needed more in the planting season due to the hard nature of planting season farm work such as clearing and making hips. Related to the results in Table 7, farm employment and land lords' farm activities are also compliments, given the positive significant coefficients of hours the land lords spend on the farming activities and employment. This is most relevant among the medium and large scale farmers in male employee categories with no significant relevance across the categories of farmers in the female employee categories. As wages is not determined by location, employment is not also determined by location, except in the case of female employee estimates indicating weak positive employment impact of $0.11 \%$ as location tend to be rural.

Table 7. Seasonal effect on farm wages

\begin{tabular}{|c|c|c|c|c|c|c|c|c|}
\hline & \multicolumn{8}{|c|}{ Male Labourers } \\
\hline & \multicolumn{2}{|c|}{ Linear Regression } & \multicolumn{6}{|c|}{ Quantile Regressions } \\
\hline \multirow{2}{*}{$\begin{array}{l}\text { Dep. var. log } \\
\text { (wages) }\end{array}$} & & & \multicolumn{2}{|c|}{25 percentile } & \multicolumn{2}{|c|}{50 percentile } & \multicolumn{2}{|c|}{75 percentile } \\
\hline & Coef. & P-value & Coef. & P-value & Coef. & P-value & Coef. & P-value \\
\hline $\begin{array}{l}\text { Seasonid } \\
\text { (harvest=1) }\end{array}$ & $-0.263 * * *$ & 0.000 & 0.000 & 1.000 & 0.000 & 1.000 & $-0.245^{* * *}$ & 0.001 \\
\hline
\end{tabular}


SEASONAL LABOUR MARKET RIGIDITIES: IMPACT ON FARM EMPLOYMENT AND WAGES IN NIGERIA

\begin{tabular}{|c|c|c|c|c|c|c|c|c|}
\hline Lognohrswork & $0.197 * * *$ & 0.000 & 0.000 & 1.000 & 0.000 & 1.000 & $0.383 * * *$ & 0.000 \\
\hline $\begin{array}{l}\begin{array}{l}\text { Location } \\
\text { (rural=1) }\end{array} \\
\end{array}$ & -0.064 & 0.302 & 0.000 & 1.000 & 0.000 & 1.000 & -0.070 & 0.513 \\
\hline _cons & $6.841 * * *$ & 0.000 & $6.215^{* * *}$ & 0.000 & $6.908^{* * *}$ & 0.000 & $6.984 * * *$ & 0.000 \\
\hline \multicolumn{9}{|l|}{ Statistics } \\
\hline $\begin{array}{l}\text { R2/Psuedo } \\
\text { R2 }\end{array}$ & 0.000 & & 0.000 & & \multicolumn{2}{|l|}{0.016} & \multicolumn{2}{|l|}{0.012} \\
\hline F-statistics & $16.35^{* * *}$ & & & & & & & \\
\hline Obs & 4141 & & 4141 & & 4141 & & 4141 & \\
\hline \multicolumn{9}{|c|}{ Female labourers } \\
\hline & Linear Regr & ression & \multicolumn{6}{|c|}{ Quantile Regressions } \\
\hline \multirow{2}{*}{$\begin{array}{l}\text { Dep. var. log } \\
\text { (wages) }\end{array}$} & & & \multicolumn{2}{|l|}{25 percentile } & \multicolumn{2}{|l|}{50 percentile } & \multicolumn{2}{|l|}{75 percentile } \\
\hline & Coef. & P-value & Coef. & P-value & Coef. & P-value & Coef. & P-value \\
\hline $\begin{array}{l}\text { Seasonid } \\
\text { (harvest=1) }\end{array}$ & 0.018 & 0.672 & $0.223 * * *$ & 0.003 & 0.000 & 1.000 & -0.028 & 0.620 \\
\hline lognohrswork & $0.268 * * *$ & 0.000 & 0.000 & 0.278 & 0.000 & 1.000 & $0.369 * * *$ & 0.000 \\
\hline $\begin{array}{l}\begin{array}{l}\text { Location } \\
\text { (rural=1) }\end{array} \\
\end{array}$ & -0.013 & 0.853 & 0.000 & 1.000 & 0.000 & 1.000 & -0.169 & 0.273 \\
\hline _cons & $6.121 * * *$ & 0.000 & $5.991 * * *$ & 0.000 & 6.397 & 0.000 & $6.492 * * *$ & 0.000 \\
\hline \multicolumn{9}{|l|}{ Statistics } \\
\hline $\begin{array}{l}\text { R2/Psuedo } \\
\text { R2 }\end{array}$ & 0.016 & & 0.005 & & 0.000 & & 0.009 & \\
\hline F-statistics & $9.08^{* * *}$ & & & & & & & \\
\hline Obs & 1645 & & 1645 & & 1645 & & 1645 & \\
\hline
\end{tabular}

Source: Computed using STATA

Note: $* * *$ implies significance at $1 \%$.

Table 8. Seasonal effect on farm employment

\begin{tabular}{|c|c|c|c|c|c|c|c|c|}
\hline & \multicolumn{8}{|c|}{ Male Labourers } \\
\hline & \multicolumn{2}{|c|}{ Linear Regression } & \multicolumn{6}{|c|}{ Quantile Regressions } \\
\hline & & & \multicolumn{2}{|c|}{25 percentile } & \multicolumn{2}{|l|}{50 percentile } & \multicolumn{2}{|l|}{75 percentile } \\
\hline & Coef. & P-value & Coef. & P-value & Coef. & P-value & Coef. & P-value \\
\hline seasonid & $-0.137^{* * *}$ & 0.000 & - & - & $-0.150^{* * * *}$ & 0.010 & $-0.076^{* * * *}$ & 0.036 \\
\hline lognohrswork & $0.223^{* * *}$ & 0.000 & - & - & $0.293^{* * *}$ & 0.002 & $0.161^{* * *}$ & 0.001 \\
\hline locat_rl & 0.009 & 0.785 & - & - & 0.053 & 0.102 & 0.029 & 0.547 \\
\hline _cons & $0.872^{* * *}$ & 0.000 & - & - & $0.723^{* * *}$ & 0.000 & $1.321 * * *$ & 0.000 \\
\hline
\end{tabular}




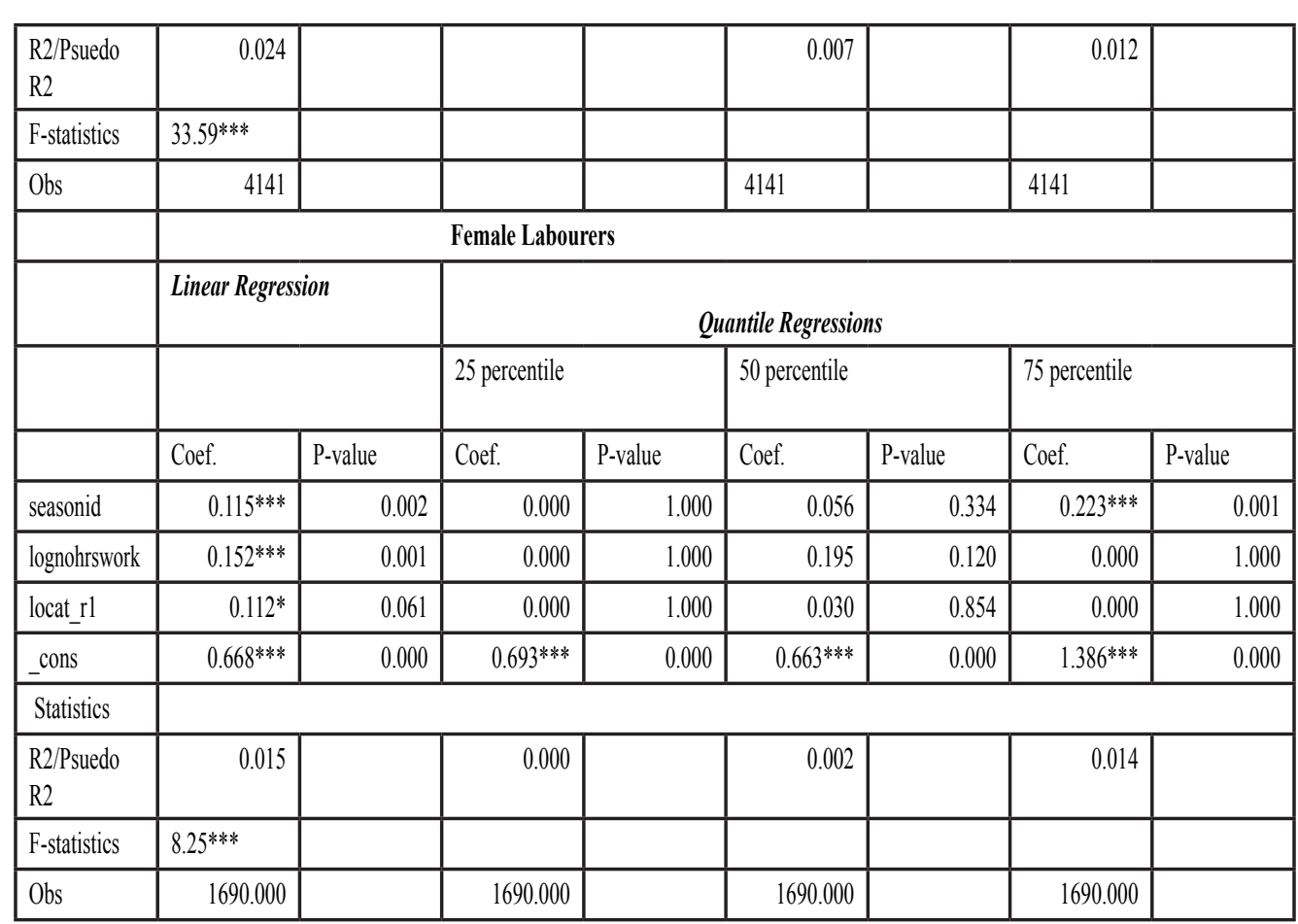

Source: Computed using STATA

Note: $*$, *** implies significance at $10 \%$ and $1 \%$, respectively. - indicates observation too few to estimate the categories of male employment at the lowest 25 percentile.

\section{Conclusion and policy issues}

This study investigated sensitivity of the agricultural wages and employment to seasonal demand and productivity conditions among Nigerian farmers. An analytical model that incorporates seasonal variations in rural farm employment and wages was developed in a way that is consistent with the data. The developed framework supports the hypothesis that seasonal labour market imperfections affects farm employment and wages differently. This was tested empirically using the Living Standards Measurement Study-Integrated Surveys on Agriculture (LSMS-ISA) for Nigeria in the wave 2 panel studies for the year 2012/2013.

During harvest, the study finds that, farmers are significantly less likely to employ male labourers; hence, male labourers are paid lesser wages. The opposite is the case for female labourers who are more likely to be employed and paid higher wages in harvest. The decline in male employment and an increase in female employment during harvest are stronger for medium scale farmers and large scale farmers, respectively. Also, the decline in male wages and increase in female wages during harvest is stronger for large scale farmers and low scale farmers, respectively. These results suggest that seasonality rigidity has different impacts on male and female farm employment and wages. 
Reducing seasonal exactingness will minimise imperfections farm employment and wages. However, this requires a concerted effort at designing agricultural policies that account for seasonal cycles in rainfall, production, labour requirements and employment opportunities. Some of the approaches at reducing seasonality include effective irrigation system, mixed cropping, improved agricultural mechanisation, counter-seasonal grain market operations and subsidised input distribution. These approaches are expected to enhance overlapping cropping thus making agricultural production sustainable.

\section{References}

1. Basu, A. K. (2011): Impact of Rural Employment Guarantee Schemes on Seasonal Labour Markets: Optimum Compensation and Workers' Welfare. IZA discussion paper no. 5701

2. Bardhan, P. K. (1979): Wages and Unemployment in a Poor Agrarian Economy: A Theoretical and Empirical Analysis, Journal of Political Economy, vol. 87, no. 3, pp. 479 - 500.

3. Bardhan, P. K. (1983): Labour-Tying in a Poor Agrarian Economy: A Theoretical and Empirical Analysis, Quarterly Journal of Economics, vol. 98, no. 3, pp. 501 514.

4. Benjamin, D. (1992): Household Composition, Labour markets, and Labour Demand: Testing for Separation in Agricultural Household Models, Econometrica, vol. 60, no. 2, pp. 287-322.

5. Canwat, V. (2012): Modelling seasonal farm labour demands: What can we learn from rural Kakamega district, western Kenya?, International Journal of Development and Sustainability, vol. 1 no. 2, pp. 195-211.

6. Card, D., Krueger, A.B. (1994): Minimum Wages and Employment: A Case Study of the Fast-Food Industry in New Jersey and Pennsylvania, The American Economic Review, vol. 84, no. 4, pp. 772-793.

7. Devereux, S., Longhurst, R. (2009): Seasonal Neglect? Aseasonality in Agricultural Project Design. $\quad$ Paper prepared for the international conference ,Seasonality Revisited, Institute of Development Studies, Brighton, UK, 8-10 July 2009, (available at: http://www.future-_ agricultures.org/search-documents/ seasonality-revisited/background-report-and- papers/997-s ea s on al-ne glectaseasonality-in-agricultural-project-design/file)

8. Eswaran, M., Kotwal, A. (1985): A Theory of Two-Tier Labour Markets in Agrarian Economies, The American Economic Review, vol. 75, no. 1, pp. 162-177

9. Federal Ministry of Agriculture and Rural Development and the World Bank (2013): Integrated Surveys on Agriculture, A Report by the National Bureau of Statistics in Collabouration with the Federal Ministry of Agriculture and Rural Development and the World Bank 
10. Federal Ministry of Agriculture and Rural Development and the World Bank (2014): Integrated Surveys on Agriculture, A Report by the National Bureau of Statistics in Collabouration with the Federal Ministry of Agriculture and Rural Development and the World Bank

11. Grimard, F. (2000): Rural Labour Markets, Household Composition, and Rainfall in Cote d'Ivoire, Review of Development Economics, pp. 70-86.

12. Gulesci, S. (2011): Labour-Tying and Poverty in a Rural Economy: Evidence from Bangladesh, London School of Economics.

13. Gulesci, S. (2015): Labour-tying and poverty in a rural economy: evidence from Bangladesh, CEPR, NBER and Università Bocconi Working Paper no. 460

14. Le, K.T. (2011): Separation Hypothesis Tests in the Agricultural Household Model, Oxford University Press.

15. McCullough, E.B. (2015): Labour Productivity and Employment Gaps in Sub-Saharan Africa, World Bank Group, Policy Research Working Paper no. 7234.

16. National Bureau of Statistics (2015): Employment (Job) Creation Survey, 3rd Quarter 2015.

\section{Appendix}

Table A1. Harvest sales categories

\begin{tabular}{|c|c|c|}
\hline Harvest sales categories & $\begin{array}{l}\text { No of } \\
\text { farmers }\end{array}$ & Percentage \\
\hline 0 & 41 & 0.42 \\
\hline 100000 & 8,866 & 89.85 \\
\hline 200000 & 660 & 6.69 \\
\hline 300000 & 162 & 1.64 \\
\hline 400000 & 52 & 0.53 \\
\hline 500000 & 35 & 0.35 \\
\hline 600000 & 9 & 0.09 \\
\hline 700000 & 6 & 0.06 \\
\hline 800000 & 19 & 0.19 \\
\hline 900000 & 4 & 0.04 \\
\hline 1000000 & 3 & 0.03 \\
\hline 2600000 & 11 & 0.11 \\
\hline Total & 9868 & 100 \\
\hline
\end{tabular}

Source: Computed using STATA 